\title{
CARDIORESPIRATORY FITNESS AND CARDIOMETABOLIC RISK FACTORS AMONG UNIVERSITY PROFESSORS
}

\author{
APTIDÃO CARDIORRESPIRATÓRIA E FATORES DE RISCO CARDIOMETABÓLICO \\ ENTRE PROFESSORES UNIVERSITÁRIOS \\ APTITUD CARDIORRESPIRATORIA Y FACTORES DE RIESGO CARDIOMETABÓLICO \\ ENTRE PROFESORES UNIVERSITARIOS
}

Original Article

ArTIGo ORIGINAL

Artículo Original

\author{
Jaqueline de Oliveira Santana ${ }^{1,2}$ \\ (Physical Education Professional) \\ Juliana Vaz de Melo Mambrini ${ }^{3}$ \\ (Statistician) \\ Sérgio Viana Peixoto 3,4 \\ (Biologist)

\begin{abstract}
1. Programa de Pós-Graduação em Ciências da Saúde, Instituto René Rachou, Fiocruz Minas, Belo Horizonte, MG, Brazil.

2. Instituto Federal de Ciência e Tecnologia de Minas Gerais (IFMG), Campus Avançado Itabirito, MG, Brazil.

3. Instituto René Rachou, Fiocruz Minas, Belo Horizonte, MG, Brazil. 4. Universidade Federal de Minas Gerais (UFMG), Escola de Enfermagem, Belo Horizonte, MG, Brazil.
\end{abstract}

\section{Correspondence:}

Jaqueline de Oliveira Santana. Rua João Arantes, 152/201, Cidade Nova, Belo Horizonte, Minas Gerais, Brazil. 31170-240.

jaquelineosantana@gmail.com

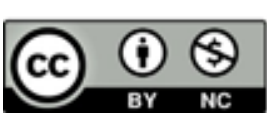

\begin{abstract}
Introduction: Cardiorespiratory fitness (CF) is associated with mortality and the development of cardiovascular disease, in addition to being related to work capacity. Objectives: This study aimed to verify the demographic, cardiometabolic and behavioral factors associated with CF in a representative sample of professors from a public university in Minas Gerais, Brazil. Methods: This is a cross-sectional study which evaluated, in addition to the CF, age, sex, glycemia, triglycerides, LDL and HDL cholesterol, C-reactive protein, body mass index (BMI), waist circumference, and physical activity (PA). The association between CF and cardiometabolic risk factors was estimated by logistic regression to obtain the odds ratios and respective confidence intervals (95\%). Results: After adjustment, it was observed that professors with lower levels of CF were older, female, had higher BMI and a greater chance of being physically inactive. Conclusion: In general, the results show that the probability of low CF increases with the increase in BMI, in addition to the strong association with PA practice, which is a major focus of intervention measures aimed at improving workers health and their work capacity. Level of Evidence III; Case control study.
\end{abstract}

Keywords: Physical fitness; Motor activity; Body mass index; Occupational health.

\section{RESUMO}

Introdução: A aptidão cardiorrespiratória (ApCr) está associada à mortalidade e ao desenvolvimento de doenças cardiovasculares, além de estar relacionada com a capacidade de trabalho. Objetivos: Este estudo objetivou verificar os fatores demográficos, cardiometabólicos e comportamentais associados à ApCr em uma amostra representativa de professores de uma universidade pública em Minas Gerais, Brasil. Métodos: Trata-se de um estudo seccional que avaliou, além da ApCr, idade, sexo, glicemia, triglicérides, colesterol LDL e HDL, proteína C-reativa, índice de massa corporal (IMC), circunferência da cintura e atividade física (AF). A associação entre ApCre fatores de risco cardiometabólico foi estimada pela regressão logística, obtendo-se os valores de odds ratio e respectivos intervalos de confiança (95\%). Resultados: Após ajustamento, observou-se que os professores com menores niveis de ApCr eram mais velhos, do sexo feminino, tinham maiores valores de IMC e maior chance de serem fisicamente inativos. Conclusão: Em geral, os resultados mostram que a probabilidade de baixa ApCr aumenta com a elevação do IMC, além da forte associação com a prática de AF, que constitui um importante foco das medidas de intervenção que visem a melhoria da saúde do trabalhador e de sua capacidade de trabalho. Nível de Evidência III; Estudo de caso-controle.

Descritores: Aptidão física; Atividade motora; Índice de massa corporal; Saúde do trabalhador.

\section{RESUMEN}

Introducción: La aptitud cardiorrespiratoria (ApCr) está asociada a la mortalidad y al desarrollo de enfermedades cardiovasculares, además de estar relacionada a la capacidad de trabajo. Objetivo: Este estudio tuvo como objetivo verificar los factores demográficos, cardiometabólicos y comportamentales asociados a la ApCr en una muestra representativa de profesores de una universidad pública en Minas Gerais, Brasil. Métodos: Se trata de un estudio seccional que evaluó, además de la ApCr, edad, sexo, glucemia, triglicéridos, colesterol LDL y HDL, proteína C-reactiva, índice de masa corporal (IMC), circunferencia de la cintura y actividad física (AF). La asociación entre ApCry factores de riesgo cardiometabólico fue estimada por la regresión logística, obteniéndose los valores de odds ratio y sus intervalos de confianza (95\%). Resultados: Después del ajuste, se observó que los profesores con menores niveles de ApCr eran mayores, del sexo femenino, tenían mayores valores de IMC y mayor probabilidad de serfísicamente inactivos. Conclusión: En general, los resultados muestran que la probabilidad de baja ApCr aumenta con la elevación del IMC, además de la fuerte asociación con la práctica de AF, que constituye un importante foco de las medidas de intervención que apunte a la mejora de la salud del trabajador y de su capacidad de trabajo. Nivel de Evidencia III; Estudio de caso-control.

Descriptores: Aptitud física; Actividad motora; Índice de masa corporal, Salud laboral. 


\section{INTRODUCTION}

Cardiorespiratory fitness (CF) is the ability of the cardiovascular and respiratory system to withstand physical exertion for a prolonged period, and is often considered the most important marker of health status and efficiency of the cardiorespiratory system. ${ }^{1}$ CF is related to all-cause mortality and the development of cardiovascular diseases, ${ }^{2}$ regardless of known cardiovascular risk factors. ${ }^{2,3}$

Although part of the variability in CF is genetically determined, behavioral factors such as the performance of physical activity (PA), also influence this measure. ${ }^{4}$ In the US adult population, low CF has been associated with obesity, metabolic syndrome, physical inactivity, lower $\mathrm{HDL}$ cholesterol and higher systolic pressure levels, triglycerides, non-HDL cholesterol, and triglyceride/HDL ratio. ${ }^{5}$ Recent studies among workers suggest that $\mathrm{CF}$ is a stronger indicator for cardiometabolic risk and risk of death than self-reported levels of physical activity. ${ }^{2,6}$ Moreover, use of the measure of CF should be prioritized, whenever possible, to the detriment of self-reported physical activity to predict health status and association with risk factors. ${ }^{\text {? }}$

In addition, we should emphasize that CF and musculoskeletal functioning are the aspects that produce the greatest impact on functional capacity, regarded as being of fundamental importance for the ability to work, given their significant role in the strain on workers. ${ }^{8}$ In this context, it is worth noting that malaise and sickness among workers can influence high rates of absenteeism, sick leave, and a reduction in quality of life at work, with a detrimental effect on society. ${ }^{9}$ In regard to university professors, we must consider the high risk of illness due to constant exposure to stressful situations, which is prejudicial to the educational process. Note that in Brazil and Latin American countries, there are few ${ }^{2}$ studies assessing the association between CF and cardiometabolic risk factors among workers.

This study aimed to evaluate CF in a representative sample of higher education instructors from a public university, and to verify the demographic, cardiometabolic and behavioral factors associated with CF.

\section{MATERIALS AND METHODS}

This study is of a cross-sectional design and was conducted among higher education instructors with an employment relationship at the Universidade Federal de Ouro Preto (UFOP), Ouro Preto campus in August 2013, which totaled 591 full-time members of the teaching staff. The sample was calculated to estimate the prevalence of physical inactivity (30\%), with a sampling error of 5\% and a 95\% confidence interval. There was a $20 \%$ increase for withdrawals and refusals, totaling 232 professors. This sample group subsequently underwent a random draw, using the list of teachers provided by UFOP.

UFOP has academic units on three campuses, located in the cities of Ouro Preto, Mariana and João Monlevade. The largest campus is located in the municipality of Ouro Preto (state of Minas Gerais), a city covering an area of 1,245.86 km², declared a "World Heritage Site" by the United Nations Educational, Scientific and Cultural Organization (UNESCO), and houses a population of approximately 74,036 thousand. ${ }^{10}$ Over the study period, UFOP had a total of 42 undergraduate courses (29 in Ouro Preto), 41 graduate courses in specialized fields (35 in Ouro Preto), and 17 non-degree graduate courses. Considering the three campuses, more than 15 thousand students were enrolled, and about 800 administrative technical employees and 800 lecturers/ professors were affiliated to UFOP.

The project was approved by the Institutional Review Board of UFOP and of Universidade Federal de Minas Gerais (UFMG) (08604212.5.0000.5149), and all participants signed the informed consent form.

\section{Variables and data collection}

Data collection comprised three stages (interview, physical evaluation and biochemical test) and was scheduled previously with each randomly drawn professor. The evaluators (Physical Education undergraduate students at UFOP) received training and a manual on the collection procedures. All the information for this study was collected between September 2013 and February 2015.

A face-to-face questionnaire administered in the professor's workplace was used to collect demographic information (age, sex) and level of physical activity (PA). PA was evaluated by IPAQ (International Physical Activity Questionnaire) in its short version. The instrument contains questions relating to the frequency, duration and intensity of PA in the past 7 days. The information collected through IPAQ was converted into metabolic equivalents (METs), based on the Compendium of PA. Physical inactivity was characterized by an energy expenditure in physical activities of less than 450 MET.min/week. ${ }^{11}$

The physical examination included an assessment of cardiorespiratory fitness and collection of anthropometric measurements. CF was assessed with VO2000 equipment and the test protocol used was Ellestad. Maximum/peak oxygen consumption was measured directly and determined on a basis of the highest VO2 obtained before voluntary fatigue. The volume of oxygen consumed in milliliters per kilogram of weight per minute was considered. Professors with a diagnosis of hypertension and those with systolic blood pressure greater than or equal to $140 \mathrm{mmHg}$ and/or diastolic blood pressure greater than or equal to $90 \mathrm{mmHg}$ on three different pre-test days were excluded from this test.

As regard to anthropometric measurements, waist circumference was obtained during normal expiration with a flexible and inelastic tape measure. The measurement was performed at the midpoint between the iliac crest and the last rib. A portable 100-gram precision EKS Sport weighing scale was used to measure body weight while a Sanny portable stadiometer with millimeter accuracy was used to measure the height of the individuals. These measurements were collected considering the standard procedures described in the literature, while body mass index (BMI) was calculated as the ratio between weight $(\mathrm{kg})$ and height squared $(\mathrm{m})$.

Blood samples were collected by venipuncture to perform the biochemical test. Fasting blood glucose, total cholesterol and HDL and LDL fractions, triglycerides and C-reactive protein (CRP) were analyzed. The blood was drawn after 12 hours of fasting. Plasma concentrations of Total Cholesterol (TC), HDL Cholesterol (HDL-C) and Triglycerides (TG) were determined through the enzymatic colorimetric assay $\left(\right.$ Labtest $\left.{ }^{\circledR}\right)$. LDL-C was calculated by the Friedewald equation, in $\mathrm{mg} / \mathrm{dL}$ : $\mathrm{LDL}-\mathrm{C}=\mathrm{TC}-\mathrm{HDL}-\mathrm{C}-\mathrm{TG} / 5$. Blood glucose concentration was determined using the enzymatic glucose oxidase method $\left(\right.$ Labtest $\left.^{\circledR}\right)$. Internal controls (normal and pathological) were used to validate the biochemical tests. The concentration of C-reactive protein (CRP) was measured with the chemiluminescence method (Siemens Healthcare Diagnostics Inc., LoS Angeles, CA, USA).

\section{Statistical analysis}

A descriptive analysis of the variables considered in this study was performed using percentage and mean (standard deviation), in addition to the association with CF. The chi-square test was used to compare proportions or the Student's t-test to compare means.

The CF level was divided into tertiles and dichotomized as "Iow CF" (first tertile) and "good CF" (second and third tertiles). The association between CF and cardiometabolic risk factors, considered continuous variables, was estimated by logistic regression, obtaining the odds ratio values and confidence intervals (95\%), with the performance of a crude 
analysis and another adjusted for all variables considered. The predicted odds of having low CF were subsequently estimated according to BMI values and the level of physical activity, considering the regression model adjusted for all variables.

The data were typed and checked in EpiData and the other analyses were conducted in the Stata 13.0 program.

\section{RESULTS}

Of the 163 (70.3\% of the randomized sample) professors in the study, 104 (63.8\%) participated in all stages of the research and had information for all variables included in this analysis. In regard to $C F$, this population had a mean VO2 of $33.0 \mathrm{~mL} / \mathrm{kg} / \mathrm{min}$ (standard deviation $=9.4 \mathrm{~mL} / \mathrm{kg}$ / $\mathrm{min}$ ), with variation of 13.8 to $63.6 \mathrm{~mL} / \mathrm{kg} / \mathrm{min}$, with a mean of $34.8 \mathrm{~mL} /$ $\mathrm{kg} / \mathrm{min}$ (standard deviation $=9.3 \mathrm{~mL} / \mathrm{kg} / \mathrm{min}$ ) for the men and $30.0 \mathrm{~mL}$ / $\mathrm{kg} / \mathrm{min}$ (standard deviation $=8.6 \mathrm{~mL} / \mathrm{kg} / \mathrm{min}$ ) for the women. Teachers located in the first tertile of the distribution were regarded as having low CF (<28.9 mL/kg/min).

The average age was 43.3 years (standard deviation $=9.6$ years); $65.4 \%$ were men and $28.9 \%$ were classified as physically inactive. The mean and standard deviation values of the other variables studied are described in Table 1. The group with low CF included older individuals, with a lower proportion of men and higher fasting blood glucose, waist circumference, and body mass index values (Table 1).

The logistic regression model of the association between cardiorespiratory fitness and the variables studied is presented in Table 2. After adjusting for all variables, it was possible to note that professors with lower CF levels were older, had higher BMI values and a greater chance of being physically inactive. In addition, male professors were less likely to have low CF when compared to women.

Figure 1 shows the result of the predicted probability of having low CF (first tertile) for each individual in the sample, considering adjustment for all variables considered, in relation to BMI and level of physical activity. Note that the probability of low CF in this population are always higher in physically inactive individuals, and increase with BMl elevation consistently across both groups.

Table 1. Distribution of the participants' characteristics according to cardiorespiratory fitness. Ouro Preto, MG, 2015.

\begin{tabular}{|c|c|c|c|c|}
\hline \multirow[b]{2}{*}{ Variables } & \multirow[b]{2}{*}{ Total } & \multicolumn{2}{|c|}{ Cardiorespiratory fitness } & \multirow[b]{2}{*}{$p$-value* } \\
\hline & & $\begin{array}{c}\text { Low } \\
(<28.9 \mathrm{~mL} / \mathrm{kg} / \mathrm{min} .)\end{array}$ & $\begin{array}{c}\text { Adequate } \\
(\geq 28.9 \mathrm{~mL} / \mathrm{kg} / \mathrm{min} \text {. })\end{array}$ & \\
\hline Age (years) & $43.3(9.6)$ & $47.2(10.1)$ & $41.4(8.9)$ & 0.004 \\
\hline Male sex, \% & 65.4 & 51.5 & 71.8 & 0.043 \\
\hline $\begin{array}{l}\text { Fasting blood glucose } \\
\text { (mg/dL) }\end{array}$ & $100.0(16.3)$ & $104.6(22.3)$ & $97.8(12.3)$ & 0.050 \\
\hline Triglycerides (mg/dL) & $125.3(85.1)$ & $141.6(98.3)$ & $117.8(77.8)$ & 0.185 \\
\hline $\begin{array}{l}\text { HDL cholesterol } \\
\text { (mg/dL) }\end{array}$ & $64.5(14.5)$ & $64.3(13.5)$ & $64.6(15.0)$ & 0.926 \\
\hline $\begin{array}{l}\text { LDL cholesterol } \\
\text { (mg/dL) }\end{array}$ & $113.2(28.5)$ & $111.7(32.5)$ & $113.9(26.7)$ & 0.718 \\
\hline $\begin{array}{l}\text { C-Reactive Protein } \\
\text { (mg/dL) }\end{array}$ & $2.9(3.3)$ & $3.6(3.5)$ & $2.54(3.1)$ & 0.143 \\
\hline $\begin{array}{l}\text { Waist Circumference } \\
(\mathrm{cm})\end{array}$ & $88.3(10.4)$ & $93.2(11.6)$ & $86.0(9.0)$ & 0.001 \\
\hline $\begin{array}{l}\text { Body Mass Index } \\
\left(\mathrm{kg} / \mathrm{m}^{2}\right)\end{array}$ & $24.7(3.3)$ & $26.8(3.5)$ & $23.8(2.8)$ & $<0.001$ \\
\hline Sedentary Lifestyle, \% & 28.9 & 36.4 & 25.4 & 0.249 \\
\hline
\end{tabular}

Table 2. Crude and adjusted analyses of the association between lower cardiorespiratory fitness and risk factors among university professors of a federal public institution. Ouro Preto, MG, 2015.

\begin{tabular}{c|c|c}
\hline Variables & $\begin{array}{c}\text { OR crude analysis } \\
(\mathbf{9 5 \%} \mathbf{C I})\end{array}$ & $\begin{array}{c}\text { OR adjusted analysis } \\
\mathbf{( 9 5 \% ~ C I )}\end{array}$ \\
\hline Age (years) & $1.05(1.01-1.09)^{*}$ & $1.09(1.02-1.16)^{*}$ \\
\hline Sex & $0.34(0.15-0.77)^{*}$ & $0.17(0.37-0.83)^{*}$ \\
\hline Male & 1.00 & 1.00 \\
\hline Female & $1.03(0.99-1.06)$ & $1.01(0.97-1.57)$ \\
\hline Fasting blood glucose & $1.00(0.99-1.00)$ & $1.00(0.99-1.01)$ \\
\hline Triglycerides & $1.00(0.97-1.03)$ & $0.99(0.95-1.04)$ \\
\hline HDL cholesterol & $0.99(0.98-1.01)$ & $1.00(0.98-1.02)$ \\
\hline LDL cholesterol & $1.09(0.97-1.24)$ & $1.02(0.86-1.20)$ \\
\hline C-Reactive Protein & $1.05(1.01-1.09)^{*}$ & $1.00(0.89-1.12)$ \\
\hline Waist Circumference & $1.25(1.09-1.42)^{*}$ & $1.47(1.05-2.05)^{*}$ \\
\hline Body Mass Index & & \\
\hline Sedentary Lifestyle & $1.86(0.82-4.24)$ & $4.77(1.24-18.38)^{*}$ \\
\hline Yes & 1.00 & 1.00 \\
\hline No & & \\
\hline
\end{tabular}

OR (95\% Cl): Odds Ratio and 95\% confidence intervals estimated by logistic regression. ${ }^{*} p<0.05$.

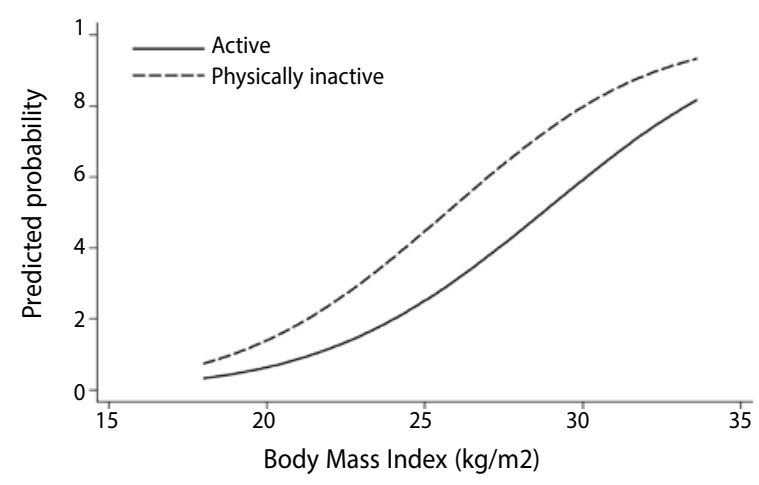

Figure 1. Predicted probability of having low cardiorespiratory fitness, according to body mass index and physical activity level. Ouro Preto, MG, 2015.

\section{DISCUSSION}

The main results of this study are related to the observation of lower CF among older individuals, women, those with higher body mass index and physically inactive individuals. On the other hand, the other cardiometabolic variables did not appear to be associated with CF in this population. The use of this indicator is relevant due to the high predictive capacity for both development of risk factors and cardiovascular events and mortality in other populations, ${ }^{12,13}$ besides being related to capacity for work. ${ }^{14}$ To the best of our knowledge, only one previous study has explored the association between CF and risk factors among workers in a Latin American country. ${ }^{2}$

The results of studies on the relationship between CF and cardiometabolic risk factors are controversial, and especially among workers with a high level of education, little is known. Age and sex are important non-modifiable risk factors that interfere with CF. Age-related changes are associated with decreased maximal heart rate, ejection fraction, maximal cardiac output, and a decrease in arteriovenous oxygen difference, which reduces CF with age, ${ }^{12,14}$ as observed in this study. In regard to sex, the higher CF values among men also corroborate previous studies. ${ }^{13,15}$ 
Higher BMI values were observed in the group with lower levels of CF. This association is not fully understood but can be attributed to the higher energy intake among individuals with low $C F$, the decrease of energy expenditure in the overweight population, or the genetic determination of these two events. ${ }^{5}$ Nevertheless, in general, a low CF is associated with a higher body weight ${ }^{3,16}$ and higher BMI values, both in the general population ${ }^{5,15}$ and among workers. ${ }^{16}$

Increased BMI and body adiposity are associated with impaired vascular endothelial function, ${ }^{17,18}$ which is related to the general functional capacity of vascular endothelial cells and their ability to synthesize and release nitric oxide (NO). ${ }^{19} \mathrm{~A}$ reduced and/or unavailable synthesis of $\mathrm{NO}$ is associated with various endothelial function abnormalities and reduced vasodilation capacity, and has been associated with a number of risk factors for CVD. ${ }^{20}$ This mechanism may explain the association found between CF and BMI in this study. In addition, previous studies have shown that BMI and WC were the anthropometric indicators most closely associated with insulin resistance, ${ }^{21}$ but improving CF can mitigate this risk. ${ }^{22}$ Therefore, there is evidence of the need for strategies geared towards controlling body adiposity, as well as increasing or maintaining CF levels among workers, considering that a high $\mathrm{BMI}$ is also considered a risk factor for loss of work capacity, exerting a negative impact by affecting cardiorespiratory and musculoskeletal capacity and favoring an increase in morbidity due to chronic diseases..$^{21,23}$

The group of professors with lower CF had a greater chance of being physically inactive. This was the variable with greatest strength of association. The relationship between CF and physical activity seems to be explained by the performance of aerobic exercises. Intervention studies have shown that these exercises, of moderate to vigorous intensity, performed frequently over weeks or months, increased CF by 10 to 20\%.24,25 Although some studies did not report this association, ${ }^{2,7,14}$ a recent meta-analysis involving 7487 adult participants showed that exercise can significantly improve CF. ${ }^{26}$ Furthermore, Grundy et al. ${ }^{5}$ observed lower levels of self-reported physical activity in the lower quintiles of CF in a cohort of US adults of both sexes. These results may suggest that the performance of physical activity favors $C F$, but the direction of this association cannot be confirmed in the current study due to its cross-sectional nature.

Studies have reported greater issues and higher expenditures with health, higher levels of disability and lower productivity among physically inactive individuals, evidencing the importance of interventions in this risk factor, which may favor CF and consequently improve cardiovascular condition and capacity for work. ${ }^{14,27}$
In this study we did not observe any significant associations between CF and biochemical markers, inflammatory markers and fasting blood glucose. Previous studies have shown controversial results in relation to these associations. ${ }^{13,28}$ Since CF is influenced by both genetic and behavioral factors, ${ }^{28}$ these disparities can be at least partly attributed to hereditary factors, which could explain differences in maximal oxygen uptake. ${ }^{29}$

The limitations of this study include the sectional design, which does not allow us to establish a temporal relationship between variables. In addition, sample loss, caused both by nonperformance of the VO2 test, and by the difficulty contacting research participants, and their refusal to participate, may have compromised the study inferences. On the other hand, this is a study that considered a specific population of workers, which measured CF and explored traditional cardiometabolic risk factors, which may have an impact on the future health of economically active adults. In addition, unlike most studies among workers, the use of a probabilistic sample is an additional advantage of the current study.

Considering that CF levels significantly influence the risk profile for $C V D$, regardless of exposure to classical risk factors and in view of the evidence that daily physical activity has a more significant effect on $\mathrm{CF}$ than genetic determinants, ${ }^{28}$ it is necessary to focus on behavioral interventions, which may favor the performance of physical activity by workers, and may also favor performance in work activitities. ${ }^{14}$

\section{CONCLUSIONS}

The likelihood of low CF increases with BMI elevation, a major marker of risk for cardiovascular events and mortality, as well as the strong association with physical activity, which is shown to be an important focal point of intervention measures aimed at improving workers'health with the consequent improvement of their work capacity.

\section{ACKNOWLEDGMENTS}

To the Fundação de Amparo à Pesquisa do Estado de Minas Gerais for their financial support (FAPEMIG CDS-APQ- 01899-12). To Kerllyn T. Coimbra, Ketlen T. de Faria, Marcone Rodrigues, Ana Daniela Damacena, Nayara Figueiredo, Taís Carvalho, Eliana J. de Paula, and Gustavo Eleutério for their contribution to the collection of data for the research. SVP holds a productivity grant from the Conselho Nacional de Desenvolvimento Científico e Tecnológico (CNPq - Brazilian National Council for Scientific and Technological Development).

All authors declare no potential conflict of interest related to this article.

AUTHORS' CONTRIBUTIONS: Each author made significant individual contributions to this manuscript. JOS (0000-0002-4741-2390)* and SVP (0000-0001-9431-2280)* participated in the conception of the study, analysis, interpretation and writing of the article; JVMM (0000-0002-0420-3062)*: participated in the analysis and discussion of the data and critical review of the content. All the authors reviewed and approved the final version of the manuscript. *ORCID (Open Researcher and Contributor ID).

\section{REFERENCES}

1. Kodama S, Saito K, Tanaka S, Maki M, Yachi Y, Asumi M, et al. Cardiorespiratory fitness as a quantitative predictor of all-cause mortality and cardiovascular events in healthy men and women: a meta-analysis. JAMA. 2009;301(19):2024-35.

2. Minder CM, Shaya GE, Michos ED, Keenan TE, Blumenthal RS, Nasir K, et al. Relation between selfreported physical activity level, fitness, and cardiometabolic risk. Am J Cardiol. 2014;113(4):637-43.

3. Myers J, McAuley P, Lavie CJ, Despres JP, Arena R, Kokkinos P. Physical activity and cardiorespiratory fitness as major markers of cardiovascular risk: their independent and interwoven importance to health status. Prog Cardiovasc Dis. 2015;57(4):306-14.
4. Martínez-Vizcaíno V, Sánchez-López M. Relationship between physical activity and physical fitness in children and adolescents. Rev Esp Cardiol. 2008;61(2):108-11.

5. Grundy SM, Barlow CE, Farrell SW, Vega GL, Haskell WL. Cardiorespiratory fitness and metabolic risk. Am J Cardiol. 2012;109(7):988-93. Erratum in: Am J Cardiol. 2013;111(1):151.

6. Gray BJ, Stephens JW, Williams SP, Davies CA, Turner D, Bracken RM, et al. Cardiorespiratory fitness is a stronger indicator of cardiometabolic risk factors and risk prediction than self-reported physical activity levels. Diab Vasc Dis Res. 2015;12(6):428-35. 
7. Freitas MP, Silva MC, Bandeira FM, Hallal PC, Rombaldi AJ. Associação entre aptidão cardiorrespiratória e nível de atividade física entre adultos jovens. Rev Bras Ativ Fis Saude. 2013;18(2):260-70.

8. IImarinen J, Tuomi K, Eskelinen L, Nygard C-H, Huuhtanen P, Klockars M. Background and objectives of the Finnish research project on aging workers in municipal occupations. Scand J Work Environ Health. 1991;17(Suppl 1):7-11.

9. Goulart Junior E, Cardoso HF, Domingues LC, Green RM, Lima TR. Trabalho e estresse: identificação do estresse e dos estressores ocupacionais em trabalhadores de uma unidade administrativa de uma instituição pública de ensino superior (IES). Revista GUAL. 2014;7(1):1-17.

10. Instituto Brasileiro de Geografia e Estatística. Perfil dos municípios 2015. [Acesso em 2016 julho 02]. Disponível em http://cidades.ibge.gov.br/xtras/perfil.php?codmun=314610.

11. Haskell WL, Lee I-M, Pate RR, Powell KE, Blair SN, Franklin BA, et al. Physical activity and public health: updated recommendation for adults from the american College of Sports Medicine and the American Heart Association. Med Sci Sports Exerc. 2007;39(8)1423-34.

12. Laukkanen JA, Mäkikallio TH, Rauramaa R, Kiviniemi V, Ronkainen K, Kurl S. Cardiorespiratory fitness is related to the risk of sudden cardiac death: a population-based follow-up study. J Am Coll Cardiol. 2010;56(18):1476-83.

13. Lee DC, Artero EG, Sui X, Blair SN. Mortality trends in the general population: the importance of cardiorespiratory fitness. J Psychopharmacol. 2010;24(11 Suppl 4):27-35

14. Martinez MC, Latorre MR, Fischer FM. Capacidade para o trabalho: revisão de literature. Cien Saude Coletiva. 2010;15(suppl.1):1553-61

15. Lakoski SG, Barlow CE, Farrell SW, Berry JD, Morrow JR Jr, Haskell WL. Impact of body mass index physical activity, and other clinical factors on cardiorespiratory fitness (from the Cooper Center longitudinal study). Am J Cardiol. 2011;108(1):34-9.

16. Wang CY, Haskell WL, Farrell SW, LaMonte MJ, Blair SN, Curtin LR, et al. Cardiorespiratory fitness levels among US adults 20-49 years of age: findings from the 1999-2004 National Health and Nutrition Examination Survey. Am J Epidemiol. 2010;171(4):426-35.

17. Brook RD, Bard RL, Rubenfire M, Ridker PM, Rajagopalan S. Usefulness of visceral obesity (waist/hip ratio) in predicting vascular endothelial function in healthy overweight adults. Am J Cardiol. 2001;88(11):1264-9.
18. Hashimoto M, Akishita M, Eto M, Kozaki K, Ako J, Sugimoto N, et al. The impairment of flow-mediated vasodilatation in obese men with visceral fat accumulation. Int J Obes Relat Metab Disord. 1998;22(5):477-84

19. Behrendt D, Ganz P. Endothelial function. From vascular biology to clinical applications. Am J Cardiol 2002:90(10C):40L-48L

20. Vallance P, Chan N. Endothelial function and nitric oxide: clinical relevance. Heart. 2001;85(3):342-50.

21. Santos RD, Timerman S, Spósito AC, Halpern A, Segal A, Ribeiro AB, et al. Diretrizes para cardiologistas sobre excesso de peso e doença cardiovascular dos Departamentos de Aterosclerose, Cardiologia Clinica e FUNCOR da Sociedade Brasileira de Cardiologia. Arq Bras Cardiol. 2002;78(Supl 1):1-13

22. Organisation Mondiale de la Santé. Vieillissement et capacité de travail: rapport d'un Groupe d'étude de l'OMS. Genève; 1993. [Série de rapports techniques no 835].

23. Pohjonen T, Ranta R. Effects of worksite physical exercise intervention on physical fitness, perceived health status, and work ability among home care workers: five-year follow-up. Prev Med 2001;32(6):465-75

24. Gormley SE, Swain DP, High R, Spina RJ, Dowling EA, Kotipalli US, et al. Effects of intensity of aerobic training on VO2 max. Med Sci Sports Exerc. 2008;40(7):1336-43.

25. Duscha BD, Slentz CA, Johnson JL, Houmard JA, Bensimhon DR, Knetzger KJ, et al. Effects of exercise training amount and intensity on peak oxygen consumption in middle-age men and women at risk for cardiovascular disease. Chest. 2005;128(4):2788-93.

26. Lin X, Zhang X, Guo J, Roberts CK, McKenzie S, Wu WC, et al. Effects of exercise training on cardiorespiratory fitness and biomarkers of cardiometabolic health: a systematic review and meta-analyses of randomized controlled trials. J Am Heart Assoc. 2015;4(7):e002014.

27. Pronk NP. Fitness of the US workforce. Annu Rev Public Health. 2015;36:131-49.

28. Zhu W, Hooker SP, Sun Y, Xie M, Su H, Cao J. Associations of cardiorespiratory fitness with cardiovascular disease risk factors in middle-aged chinese women: a cross-sectional study. BMC Women's Health. 2014; 14:62.

29. Montgomery H, Safari L. Genetic basis of physical fitness. Annu Rev Anthropol. 2007:36:391-405. 